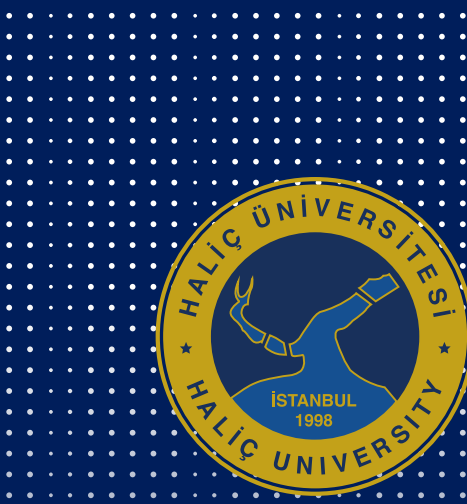

\title{
DOĞUM SONU DÖNEMDE FONKSIYYONEL DURUM VE YORGUNLUK
}

\section{Öz}

Annelik kadınların üstlendiği en zor rollerden biridir. Anne doğum sonu süreçte bir geçiş dönemindedir ve fiziksel değişikliklerine, doğum sonu rahatsızlıklarına, aile içindeki rol ve sorumluluklarına uyum sağlamak zorundadır. Kadının fonksiyonel durumu ve yorgunluk düzeyi, doğum sonu sürece uyumu ile ilişkili faktörlerdir. Annenin fonksiyonel durumundaki azalma; kendisi, bebeği ve diğer sorumluluklarına karşı ilgisini azaltabilmektedir. Doğum sonu yorgunluk ise kadının annelik davranışını, bebek bakımını, aile üyeleriyle ilişkilerini, iş performansını ve kendini gerçekleştirme davranışlarını olumsuz yönde etkilemektedir. Kadınların doğum sonu dönemde fonksiyonel durumlarında ve yorgunluk düzeylerinde zamanla iyileşme görülse de altıncı aydan sonra bile tam olarak gebelik öncesi durumlarına dönemedikleri görülmektedir. Annenin doğum sonu döneme uyum sağlaması ve gebelik öncesi durumuna dönmesi için doğum sonrası fonksiyonel durumlarının, yorgunluk düzeylerinin ve aralarındaki ilişkinin açıklanması önemlidir. Fonksiyonel durum ile yorgunluk genellikle ayrı ayrı çalışmalarda ele alınmış olup iki değişkenin birlikte incelendiği araştırma sayısı sınırlıdır. İki faktör arasındaki ilişki tanımlandığında, yorgunluk ve fonksiyonel durumun birbirini nasıl etkilediği, aralarındaki ilişkinin yönü ve hangi faktörlerden olumsuz etkilendikleri tespit edilebilecektir. Fonksiyonel durum ve yorgunluk arasındaki ilişkiyi anlamak doğum sonu dönemde annelere kanıta dayalı ve kaliteli bir bakım sunabilmek için önemlidir. Bu derlemede doğum sonu dönemde yorgunluk ve fonksiyonel durum ile iki faktör arasındaki ilişkinin açıklanması amaçlanmıştır.

*Sorumlu Yazar e mail: aysenur.atas@selcuk.edu.tr

${ }^{1}$ Selçuk Üniversitesi, Sağlık Bilimleri Fakültesi, Ebelik Bölümü, Konya, Türkiye ${ }^{2}$ Eskişehir Osmangazi, Üniversitesi Sağlık Bilimleri Fakültesi, Ebelik Bölümü, Türkiye

Nur Ataş A, Özerdoğan N. Doğum Sonu Dönemde Fonksiyonel Durum ve Yorgunluk. Haliç Üniv Sağ Bil Der. 2021; 47-54

Nur Ataş A, Özerdoğan N. Functional Situation and Fatigue In the Postpartum Period. Halic Uni J Health Sci. 2021; 47-54

Doi: 10.48124/

husagbilder. 794147

Geliş Tarihi: 12 Eylül 2021 Kabul Tarihi: 17 Ocak 2021

Anahtar Kelimeler: doğum sonu dönem, fonksiyonel durum, yorgunluk

\section{FUNCTIONAL SITUATION AND FATIGUE IN THE POSTPARTUM PERIOD}

\begin{abstract}
Motherhood is one of the most difficult roles women assume. The mother is in a transitional period in the postpartum period and and has to adapt to her physical changes, postpartum ailments, and roles and responsibilities within the family. Women's functional status and fatigue level are factors associated with her compliance with the postpartum process. The decrease in the functional status of the mother can also reduce her interest in herself, the baby and other responsibilities. Postpartum fatigue poorly affects women's maternal behavior, baby care, relationships with family members, job performance and self-actualization. Although women's functional status and fatigue levels improve over time in the postpartum period, it is seen that they cannot fully return to their pre-pregnancy state even after the sixth month. In order for the mother to adapt to the postpartum period and return to her previous state of pregnancy, it will be important to determine the functional status and fatigue levels and the relationship between them. Functional status and fatigue are generally considered in separate studies, and the number of studies examining the two variables together is limited. When the relationship between the two factors is defined, it will be possible to determine how fatigue and functional status affect each other, the direction of the relationship between them and which factors they are adversely affected by. Understanding the relationship between fatigue and functional status is important to provide evidence-based and quality care to mothers in the postpartum period. In this study, it is aimed to explain the relationship between two factors with fatigue and functional status in the postpartum period.
\end{abstract}

Keywords: postpartum, functional status, fatigue 


\section{Giriş}

Doğum sonu dönem, oluşan fizyolojik değişikliklerin yanı sıra yeni rollerin ve sorumlulukların üstlenildiği bir dönemdir. Yaşamları boyunca birçok farklı rol üstlenen kadınlar bu dönemle birlikte annelik rolünü kazanırlar. Annelik kadınların üstlendiği en zor rollerden biridir (1). Doğum sonu süreçte bir geçiş döneminde olan anne fiziksel değişikliklerine, doğum sonu rahatsızlıklarına, aile içindeki rol ve sorumluluklarına uyum sağlamak zorundadır (2). Bu dönemde verilen bakımda kadının daha çok fiziksel sağlığı ile ilgili gereksinimlerine odaklanıldığı, sosyal ve emosyonel gereksinimlerine daha az yer verildiği belirtilmektedir (3). Kadının fonksiyonel durumu ve yorgunluk düzeyi, doğum sonu sürece uyumu ile ilişkili faktörlerdir. Fonksiyonel durum temel gereksinimleri ve günlük yaşam fonksiyonlarını yerine getirme adaptasyonuna dayalı bir kavramdır ve annenin günlük yaşamsal faaliyetlerine devam edebilmesi için önemlidir. Fonksiyonel durumdaki azalma annenin sorumlulukları ile başa çıkabilme durumunu etkilerken; yorgunluk düzeyinin fazla olması anne sağlığının bozulması, günlük aktivitelerine geç dönmesi, erken emzirmeyi bırakma, bebeğin gelişiminin gecikmesi gibi sorunlara sebep olabilmektedir (4). Annenin doğum sonu döneme uyum sağlaması ve gebelik öncesi durumuna dönmesi için doğum sonrası fonksiyonel durumlarının ve yorgunluk düzeylerinin belirlenmesi önemli olacaktır. Doğum sonrası süreçte kadınların fonksiyonel durumları ve yorgunluk düzeyleri arasındaki ilişkinin, zamanla gösterdikleri değişimin, etkileyen faktörlerin neler olduğunun bilinmesi verilen bakımın kalitesine katkıda bulunacaktır.

Doğum sonu dönemde annenin fonksiyonel durumunu yorgunluk düzeyi ile birlikte ele alan çalışma sayısı sınırlıdır (5). Bu derlemede doğum sonu dönemde annenin fonksiyonel durumu ve yorgunluk düzeyi, konu ile ilgili literatür incelenerek tanımlanmaya çalışılacaktır. Ayrıca fonsiyonel durum ve yorgunluğa etki eden faktörler ve doğum sonu dönemde fonksiyonel durumun yorgunluk düzeyi ile ilişkisi açıklanacaktır.

\section{Gereç ve Yöntem}

Derleme kapsamında İngilizce 'postpartum', 'functional status', 'functional status after childbirth', 'postpartum functional status inventory', 'maternal functioning', 'fatigue', 'postpartum fatigue', 'predictive factors'; Türkçe 'doğum sonu dönem', 'postpartum dönem', 'fonksiyonel durum' ve 'yorgunluk' arama terimleri kullanılarak Ocak-Ağustos 2020 tarihleri arasında literatür taraması yapılmıştır. Anahtar kelimeler doğrultusunda tarama; PubMed, Science Direct, Web of Science, Cochrane ve Google Scholar veri tabanları aracılığıly retrospektif olarak elektronik arama ile gerçekleştirilmiştir. Başlığında, özetinde veya metodunda fonksiyonel durum ya da yorgunluk terimi geçen 2000-2020 yılları arasında yayımlanan çalışmalar incelenmiştir. $\mathrm{Bu}$ çalışmalardan tanımlayıcı, kesitsel, meta analiz, sistematik derleme ve randomize olan/olmayan klinik çalışmalar makaleye dâhil edilmiş ve çalışmaların sonuçlarına derlemede yer verilmiştir. Türkçe ve İngilizce dışında farklı bir dilde ve Ağustos 2020 tarihinden sonra yayınlanmış olan çalışmalar çalışmaya dâhil edilmemiştir.

\section{Fonksiyonel Durum}

Fonksiyonel durum; vücut bölgelerinin kendi doğasına, yapı ve durumuna uygun olarak performans veya aktivite göstermesi olarak tanımlanmaktadır (6). Bireyin bedensel, ruhsal, sosyal iyilik halinin ve genel sağlık durumunun bir tanımlayıcısıdır. Bireyin kendine bakabilme, kendi ile ilgilenebilme ve fiziksel aktiviteleri gerçekleştirebilme yetisidir. Fiziksel fonksiyonlar (Yemek yemek, giyinmek, yürümek vb.), psikolojik fonksiyonlar (anksiyete, depresyon, özbakım vb.), bilişsel fonksiyonlar (Oryantasyon, hafiza, konuşma, dikkat vb.) ve sosyal fonksiyonlar (Kişiler arası ilişkiler, sosyal kaynaklar vb.) olmak üzere dört alandan oluşmaktadır (7). Fonksiyonel durum bireylerin sağlığını algılamasından, biyolojik ve psikolojik rahatsızlıklarından ve varsa hastalık semptomlarından etkilenmektedir (6).

\subsection{Doğum Sonu Dönemde Fonksiyonel Durum}

Doğum sonras1 fonksiyonel durum Fawcett ve ark., (1988) tarafindan, annenin bebek ve 
kendi öz bakım sorumluluklarını alması, ev işlerini, sosyal, toplumsal ve mesleki faaliyetlerini devam etmeye hazır olmasını içeren çok boyutlu bir kavram olarak tanımlanmıştır (3). Barkin'e göre ise, doğum sonrası fonksiyonel durum annenin kendi öz bakımı, bebek bakımı, anne-çocuk etkileşimi, annenin psikolojik iyi oluşu, sosyal destek, yönetim ve uyum dahil olmak üzere çok çeşitli fonksiyonel alanları kapsamaktadır (8). Araştırmalarda annenin doğum sonu fonksiyonel durumunu belirlemek için çoğunlukla Fawcett tarafindan Roy Adaptasyon Modeline göre geliştirilen "Doğum Sonrası Fonksiyonel Durum Envanteri (Inventory of Functional Status After Childbirth-IFSAC)" kullanılmaktadır. IFSAC doğum sonrası fonksiyonel durumu ölçecek şekilde düzenlenmiş ve özellikle doğum sonrası dönemde birinci, ikinci ve üçüncü derece rollerin değerlendirilmesine izin veren tek araçtır (9). Doğum sonrası dönemdeki kadının ilk rolü; kendi öz bakım aktivitelerini yerine getirmesidir. İkinci rolü; ev işleri, bebek bakım sorumluluğu, mesleki aktivitelerinden oluşmaktadır. Üçüncü rolü ise sosyal ve toplumsal aktiviteleri olarak belirtilmektedir. IFSAC ölçeğinde alınan yüksek puanlar fonksiyonel durumun iyi olduğunu göstermektedir (3).

\subsection{Annelerin Doğum Sonu Dönemde Fonksiyonel Durumları}

Annelerin doğum sonu dönemde fonksiyonel durumları, ilgili literatür 1şığında tanımlanmaya çalışılmıştır. McVeigh, (2000) doğum sonras1 fonksiyonel durum ve sosyal destek arasındaki ilişkiyi araştırmak amacıyla gerçekleştirdiği çalışmasında annelerden altıncı haftada, üçüncü ayda ve altıncı ayda IFSAC verilerini toplamıştır. Doğum sonu altıncı haftada düşük IFSAC puanları görülmekte iken, altınc1 ayda puanların yükseldiğini belirtmiştir. Genel olarak doğum sonrası zaman ilerledikçe, kadınların fonksiyonel durumlarının iyileştiğini bulmuştur. En yüksek ortalama puanların bebek bakımı, ev işi aktiviteleri ve kişisel bakım alanında, en düşük puanların ise sosyal ve toplumsal aktiviteler alanında olduğunu saptamıştır (10). Şanlı ve Öncel, (2014)'in çalışmaları da benzer şekilde doğum sonrası dönem ilerledikçe, kadınların fonksiyonel durumlarının iyileştiği yönündedir. Ancak çalışmada annelerin altıncı ayda bile hala doğum öncesi fonksiyonel durumlarına tamamen geri dönemedikleri saptanmıştır (2). Gerçekleştirilen başka bir çalışmada da kadınların fonksiyonel durumlarının zamanla eski durumuna dönse de, fonksiyonel durumun alt başlıklarından olan öz bakım, sosyal ve toplumsal faaliyet alanlarının tam olarak eski haline dönmediği bildirilmiştir (11). Fathi ve ark., (2018)'da araştırmalarında fonksiyonel durumun alt başlıkları arasında annelerin, bebek bakımı alanında en yüksek, sosyal ve toplumsal alanda en düşük puanı aldıklarını saptamışlardır (1).

Genel olarak araştırma sonuçlarına bakıldığında, annelerin zamanla fonksiyonel durumlarında iyileşme görülse de fonksiyonel durumlarının alt alanlarında altıncı aydan sonra bile tam olarak gebelik öncesi duruma dönüş olmadığ1 görülmektedir. Özellikle öz bakım ve sosyal toplumsal faaliyetleri alanlarında kadınlar daha düşük puanlara sahiptir.

\subsection{Doğum Sonu Dönemde Fonksiyonel Duruma Etki Eden Faktörler}

Doğum sonu dönemde fonksiyonel duruma etki eden bazı faktörler bulunmaktadır. Yaş, eğitim düzeyi, eş desteği ve sosyal destek, parite, doğum şekli, fiziksel aktivite, ruhsal durum bu faktörler arasında yer almaktadır. Doğum sonu dönemde fonksiyonel durumu etkileyen faktörlerle ilgili sonuçlar Tablo 1.'de verilmiştir.

Şanlı ve Öncel, (2014) yaş arttıkça kadınların fonksiyonel durumlarında artma olduğunu bildirmişlerdir (2). Benzer şekilde Fathi ve ark., (2018)'da 25-35 yaş arası annelerin daha genç olanlara göre doğum sonu dönemde daha yüksek fonksiyonel duruma sahip olduğunu belirlemişlerdir (1).

Eğitim düzeyi ile doğum sonu dönemdeki fonksiyonel durum arasındaki ilişkiyi inceleyen çalışmalarda; Fathi ve ark., (2018) annenin eğitim seviyesinin yüksek olmasının yüksek maternal fonksiyon ile ilişkili olduğunu belirtmişlerdir (1). Şanlı ve Öncel, (2014)'de çalışmalarında ilkokul mezunu olan kadınların altıncı haftada bebek bakım sorumluluklarında, üniversite ve üstü eğitimi olan kadınların ise üçüncü ve altıncı 
aylarda öz bakım faaliyetlerinde diğer gruplara göre yüksek fonksiyonel durum gösterdiklerini bildirmişlerdir (2).

Eş desteği ve sosyal desteğin etkisini inceleyen çalışmalarda; McVeigh, (2000) eşten destek alma ile doğum sonrası fonksiyonel durum arasında pozitif bir ilişki bulunduğunu saptamıştır. Çalışmasında eşten destek alan annelerin fonksiyonel durumunun bebek bakımı, öz bakım, sosyal ve toplumsal faaliyetler alt alanlarında anlamlı şekilde daha yüksek olduğu saptanmıştır. Ancak eş haricinde diğer kişilerden alınan desteğin, bu fonksiyonel durumlar ile ilişkili olmadığ 1 da aynı araştırmada belirtilmiştir (10). Şanlı ve Öncel, (2014) ise çalışmalarında bebek bakımı ve ev işlerinde destek almayan kadınların, normal fonksiyonel durumlarına daha erken döndüklerini bildirmişlerdir (2).

Parite ile doğum sonu dönemdeki fonksiyonel durum arasındaki ilişkiyi inceleyen çalışmalarda; multiparların fonksiyonel durumlarının primiparlardan daha yüksek olduğu belirlenmiştir (1, 5). McVeigh, (2000) bu sonucu destekler nitelikteki araştırmasında primiparlarda üçüncü ve altıncı aylarda ev işi aktiviteleri, bebek bakımı ve toplam ortalama IFSAC puanlarının multiparlara göre önemli ölçüde daha düşük olduğunu saptamıştır (10). Aktan, (2010) ise çalışmasında farklı bir şekilde parite ile fonksiyonel durum arasında negatif yönlü bir ilişkinin olduğunu belirtmiştir. Kadınlarda parite arttıkça fonksiyonel durumun azaldığını saptamıştır (12). Fonksiyonel durumun alt alanları pariteye göre değişiklik gösterebilmektedir. Yapılan bir çalışmada kadınların sahip oldukları çocuk sayısının artmasıyla birlikte ev içi faaliyetleri, bebek bakımı ve toplam IFSAC puanında artma, öz bakım alanında ise azalma olduğu gösterilmiştir (2).

Doğum şeklinin etkisi araştırılmış; Abushaikha ve ark., (2018) vajinal doğum yapan annelerin sezaryen doğum yapan annelere kıyasla daha iyi fonksiyonel duruma sahip olduklarını belirtmişlerdir (5). Benzer şekilde Şanlı ve Öncel, (2014)'de çalışmalarında vajinal yolla doğum yapan kadınların bebek bakımına ilişkin fonksiyonel durumlarına sezaryen ile doğum yapan kadınlardan daha çabuk döndüklerini saptamışlardır (2).
Fiziksel olarak aktif olan kadınların doğum sonu fonksiyonel durumlarının daha yüksek olduğu belirtilmektedir. Barbacsy-MacDonald, (2011) çalışmasında doğum sonrası altıncı haftada fiziksel olarak aktif kadınların, düşük/orta derecede aktif olan kadınlara göre daha yüksek fonksiyonel durum sergilediklerini bildirmiştir. Fiziksel olarak aktif kadınların toplam IFSAC skorları ve öz bakım aktiviteleri daha yüksektir (11).

Doğum sonu dönemde anksiyete ve depresyon, fonksiyonel durumu etkileyebilmektedir. McVeigh, (2000) çalışmasında doğum sonrası altıncı haftada, maternal anksiyete ile fonksiyonel durum arasında negatif bir ilişki tespit etmiştir. Anksiyete düzeyi arttıkça toplam IFSAC puanı, sosyal ve toplumsal aktivite ve öz bakım aktivitesi puanı azalmıştır (13). Aktan'ın (2010) çalışma sonucu da benzer şekilde doğumdan sonra fonksiyonel durum ile doğum sonu anksiyete arasında negatif bir ilişki olduğu yönündedir (12). Depresyon ile fonksiyonel durum ve alt alanları arasında da aynı şekilde negatif ilişki olduğu belirtilmektedir (1).

Sonuç olarak artan yaş, annenin eğitim düzeyinin yüksek olması, eşten destek alma, vajinal doğum yapma, fiziksel aktivite yapmanın fonksiyonel durumu artırdığ 1 ve iyileştirdiği çalışmalar 1Şı̆̆ııda görülmektedir. Sezaryen doğum yapma, anksiyete ve depresyon gibi ruhsal problemlerin ise fonksiyonel durumu azalttığı söylenebilir.

\section{Yorgunluk}

Yorgunluk bireyin fiziksel ve mental iş kapasitesini azaltan, normal rutinlerde bozulmaya sebep olan (14), tüm bedeni etkileyen hafif bir tükenmişlikten, katlanılamaz bir bitkinliğe kadar değişebilen, hoş olmayan subjektif bir semptomdur (15). Yorgunluk; bireyin çalışma ortamında verimliliğini engellemesi, kendisi ve ailesini ekonomik yönden olumsuz etkilemesi, bağıml1lığı artırması, fiziksel ve emosyonel hastalıklarla birlikte görülme sıklığının artışı sebebiyle önemli bir problemdir. Yorgunluk kontrol altına alınmaması durumunda bireyin temel insani gereksinimlerine ve yaşam kalitesine olumsuz yönde etki yapan bir duruma dönüşebilmektedir $(15,16)$. 
Tablo 1. Derlemeye Alınan Çalışmaların Özellikleri

\begin{tabular}{|c|c|c|c|c|c|}
\hline & $\begin{array}{l}\text { Fathi ve ark., } \\
(2018)(1)\end{array}$ & $\begin{array}{l}\text { McVeigh, (2000) } \\
(10,13)\end{array}$ & $\begin{array}{l}\text { Şanlı ve Öncel, (2014) } \\
\text { (2) }\end{array}$ & $\begin{array}{l}\text { Abushaikha ve ark., } \\
(2018)(5)\end{array}$ & Aktan, (2010)(12) \\
\hline $\begin{array}{l}\text { Araştırma } \\
\text { Konusu }\end{array}$ & $\begin{array}{l}\text { Fonksiyonel } \\
\text { durum }\end{array}$ & $\begin{array}{l}\text { Fonksiyonel } \\
\text { Durum }\end{array}$ & Fonksiyonel Durum & $\begin{array}{l}\text { Fonksiyonel durum ve } \\
\text { yorgunluk }\end{array}$ & $\begin{array}{l}\text { Fonksiyonel } \\
\text { Durum }\end{array}$ \\
\hline $\begin{array}{l}\text { Araştırma } \\
\text { Tasarımı }\end{array}$ & Kesitsel & Longitudinal & Tanımlayıcı ve analitik & Kesitsel-Korelasyon & \\
\hline Sonuç & $\begin{array}{l}\text { Annenin yaş ve } \\
\text { eğitim düzeyi } \\
\text { ile fonksiyonel } \\
\text { durumu arasında } \\
\text { ilişki olduğunu } \\
\text { belirtmişlerdir. }\end{array}$ & $\begin{array}{l}\text { Annenin parite, eş } \\
\text { desteği, maternal } \\
\text { anksiyete ile } \\
\text { fonksiyonel } \\
\text { durumu arasında } \\
\text { ilişki olduğunu } \\
\text { belirtmiştir. }\end{array}$ & $\begin{array}{l}\text { Annenin yaş, eğitim } \\
\text { düzeyi, sosyal destek, } \\
\text { doğum şekli ile } \\
\text { fonksiyonel durumu } \\
\text { arasında ilişki olduğunu } \\
\text { belirtmişlerdir. }\end{array}$ & $\begin{array}{l}\text { Annenin doğum } \\
\text { şekli ile fonksiyonel } \\
\text { durum arasında } \\
\text { ilişki olduğunu } \\
\text { belirtmişlerdir. } \\
\text { Yorgunluk ile } \\
\text { fonksiyonel durum } \\
\text { arasında ilişki } \\
\text { bulunmadığını } \\
\text { saptamışlardır. }\end{array}$ & $\begin{array}{l}\text { Annenin parite ve } \\
\text { anksiyete düzeyi } \\
\text { ile fonksiyonel } \\
\text { durumu arasında } \\
\text { ilişki olduğunu } \\
\text { belirtmiştir. }\end{array}$ \\
\hline
\end{tabular}

\subsection{Doğum Sonu Dönemde Yorgunluk}

Doğum sonu yorgunluk, kadının kendini normalden daha negatif ve daha az yeterli hissetmesine sebep olmaktadır (17). Doğum sonras1 dönemde yaşanan yorgunluk, annenin fonksiyonel durumundaki düzelmeyi, annelik davranışını, bebek bakımını, aile üyeleriyle ilişkilerini, iş performansını ve kendini gerçekleştirme davranışlarını olumsuz yönde etkilemektedir (18). Yorgunluğun doğumdan hemen sonra en yüksek seviyede olduğu ve ilerleyen haftalarda azaldığ1 bildirilmiştir (19). Ancak doğumdan sonra bir yıla kadar uzayabileceği de bildirilmektedir (5). Yorgunluk doğumdan sonra yaygın ve hatta beklenen bir durum olsa da, şiddetli doğum sonu yorgunluk kadınların sağlığı ve aktiviteleri üzerinde; anne sağlığının bozulması, annenin günlük yaşamsal faaliyetlerine geç dönmesi, erken emzirmeyi bırakma ve bebeğin gelişiminin gecikmesi gibi olumsuz etkilere sahiptir $(4,20)$. Ayrıca doğum sonrası yorgunluk skorlarının yüksek olması, bebek bakımı faaliyetlerinde daha fazla zorluk çekmeyle ve daha az anne-bebek bağlanması ile ilişkili olabilmektedir (21). Araştırmalarda annenin doğum sonu dönemde yorgunluk düzeylerini belirlemek için Yoshitake tarafindan geliştirilen ve daha sonra doğum sonu dönemdeki kadınlar için revize edilen yorgunluk semptom ölçeği $(4,5)$, yorgunluk şiddeti ölçeği
(22), yorgunluk değerlendirme ölçeği (23) gibi ölçekler kullanılmaktadır.

\subsection{Annelerin Doğum Sonu Dönemde Yorgunluk Düzeyi}

Araştırmalar doğum sonu dönemde karşılaşılan en sık sağlık sorunlarından birinin yorgunluk olduğunu göstermektedir $(24,25)$. Gialloa ve ark., (2015) doğum sonu erken dönemde maternal yorgunluk durumu ile ilişkili faktörleri araştırdıkları çalışmalarında doğumdan yaklaşık üç ay sonra maternal yorgunluğun orta ve yüksek düzeyde olduğunu, zaman içerisinde yorgunluk ciddiyetinde çok az düzelme veya hiç değişiklik olmadığını bulmuşlardır (22). Abushaikha ve ark., (2018)'da benzer şekilde çalışmalarında kadınların doğum sonu dönemde orta düzeyde yorgunluk deneyimlediklerini saptamışlardır (5).

\subsection{Doğum Sonu Dönemde Yorgunluk Düzeyini Etkileyen Faktörler}

Doğum sonu dönemde yorgunluk düzeyine etki eden birtakım faktörler bulunmaktadır. Yorgunluk düzeyi ile ilgili yapılan araştırmalarda doğum sonu dönemde yorgunluğu etkileyen faktörlerle ilgili sonuçlar Tablo 2.'de verilmiştir.

Badr ve Zauszniewski, (2017) çalışmalarında doğum sonrası yorgunluğu etkileyen faktörlerin meta-analizini yapmışlardır. Yorgunluk 
için eğitim düzeyi, yaş, doğum sonu kanama, enfeksiyon ve çocuk bakımı zorluklarının küçük düzeyde; fizyolojik hastalıkların orta düzeyde, düşük ferritin düzeyi, düşük hemoglobin düzeyi, uyku sorunlar1, stres, kayg1, emzirme sorunları ve depresyonun ise büyük düzeyde etki oluşturduğunu bildirmişlerdir (26). Giallo ve ark., (2015) araştırmalarında doğum sonu dönemde yüksek yorgunluk seviyelerinin; genç ve ileri anne yaşı, sosyoekonomik dezavantajın fazla olması, sağlı̆̆ korumaya yönelik davranışları gerçekleştirme konusunda düşük öz yeterlilik düzeyi ve düşük uyku kalitesi ile ilişkili olduğunu saptamışlardır (22).

Giallo ve ark., (2011) araştırmalarında doğum sonrası dönemde maternal yorgunluk ve depresyonun değerlendirilmesi üzerine çalışmışlar ve depresyon ile yorgunluk arasında orta düzeyde ilişki bulmuşlardır (23). Aksu ve ark., (2017)'da çalışmalarında, doğum sonrası ilk altıncı haftada yorgunluk bildiren kadınların çoğunluğunda yüksek depresyon skorları bulunduğunu ve yorgunlukla birlikte doğum sonu depresyon riskinin arttığını tespit emişlerdir (25). Taylor ve Johnson'da (2013) doğum sonu dönemde artmış depresif semptom ve anksiyetenin, yorgunluk ile ilişkisi olduğunu saptamışlardır (27).

Doğum şekli ile doğum sonu dönemdeki yorgunluk düzeyi arasındaki ilişkiyi inceleyen çalışmalarda; doğum şekli ile kadınların yorgunluk düzeyleri arasında ilişki bulunmuştur. Yorgunluk düzeyinin sezaryen doğum yapan kadınlarda, vajinal doğum yapanlara göre daha yüksek olduğu belirlenmiştir $(5,21)$. Yapılan farklı bir çalışmada ise doğum şeklinin doğum sonu ilk 24 saat içerisindeki yorgunluk düzeyini ve doğumdan dört hafta sonraki yorgunluk düzeyini etkilemediği belirlenmiştir (28).

Sonuç olarak genç ve ileri anne yaşı, doğum sonu kanama, sezaryen doğum, enfeksiyon, uyku sorunlar1, stres ve depresyon gibi faktörlerin doğum sonu dönemde annenin yorgunluk düzeyini olumsuz etkilediği görülmektedir.

\section{Yorgunluk ve Fonksiyonel Durum Arasındaki İlişki}

Yorgunluğun artması ve fonksiyonel durumun azalması annenin kendisi, bebeği ve diğer sorumlulukları ile ilgilenme yeteneğini etkilemektedir (5). Bu nedenle anneyi, bebeği ve beraberinde bütün aileyi etkileyebilen bu iki faktörün birbiri ile ilişkisini belirlemek önemlidir. Fonksiyonel durum ve yorgunluğu ele alan sınırlı çalışmalardan biri, doğum sonu dönemde yorgunluk ile fonksiyonel durum arasında anlamlı bir ilişki bulamamıştır (5). Bunun tersine bir diğer çalışma ise yüksek zihinsel ve fiziksel yorgunluğun, doğum sonrası düşük fonksiyonel durumla ilişkili olduğunu saptamıştır (11). Benzer bir çalışmada da doğum sonu yorgunluk yaşayan kadınların daha az fonksiyonel duruma sahip oldukları ve fonksiyonel durumun öz bakım alanında tam olarak eski haline tekrar dönme oranının çok düşük olduğu bildirilmiştir (18).

Tablo 2. Derlemeye Alınan Çalışmaların Özellikleri

\begin{tabular}{|l|l|l|l|l|l|}
\hline & $\begin{array}{l}\text { Giallo ve ark., (2015), } \\
\mathbf{( 2 0 1 1 ) ( 2 2 , 2 3 )}\end{array}$ & $\begin{array}{l}\text { Aksu ve ark., } \\
\mathbf{( 2 0 1 7 ) ( 2 5 )}\end{array}$ & $\begin{array}{l}\text { Lai ve ark., } \\
\mathbf{( 2 0 1 5 ) ( 2 1 )}\end{array}$ & $\begin{array}{l}\text { Taylor ve ark., } \\
\mathbf{( 2 0 1 3 ) ( 2 7 )}\end{array}$ & $\begin{array}{l}\text { Çolak ve ark., } \\
\mathbf{( 2 0 1 9 ) ( 2 8 )}\end{array}$ \\
\hline $\begin{array}{l}\text { Araştırma } \\
\text { Konusu }\end{array}$ & Yorgunluk & Yorgunluk & Yorgunluk & Yorgunluk & Yorgunluk \\
\hline $\begin{array}{l}\text { Araştırma } \\
\text { Tasarımı }\end{array}$ & Randomize kontrol & & $\begin{array}{l}\text { Tanımlayıcı- } \\
\text { Kesitsel }\end{array}$ & $\begin{array}{l}\text { Prospektif } \\
\text { Longitudinal } \\
\text { Korelasyonel }\end{array}$ & Tanımlayıcı \\
\hline Sonuç & $\begin{array}{l}\text { Annenin yaş, } \\
\text { sosyoekonomik durum, } \\
\text { uyku, depresyon ile } \\
\text { yorgunluk düzeyi } \\
\text { arasında ilişki olduğunu } \\
\text { belirtmişlerdir. }\end{array}$ & $\begin{array}{l}\text { Annelerin } \\
\text { yorgunlukla } \\
\text { birlikte doğum } \\
\text { sonu depresyon } \\
\text { riskinin arttığını } \\
\text { tespit emişlerdir. }\end{array}$ & $\begin{array}{l}\text { Annelerin doğum } \\
\text { şekli ile yorgunluk } \\
\text { düzeyleri arasında } \\
\text { ilişki olduğunu } \\
\text { bulmuşlardır. }\end{array}$ & $\begin{array}{l}\text { Annelerin } \\
\text { depresif semptom } \\
\text { ve anksiyete } \\
\text { düzeylerinin } \\
\text { yorgunluk ile } \\
\text { ilişkisi olduğunu } \\
\text { saptamışlardır. }\end{array}$ & $\begin{array}{l}\text { Annelerin } \\
\text { doğum şeklinin } \\
\text { yorgunluğu } \\
\text { etkilemediğini } \\
\text { bulmuşlardır. }\end{array}$ \\
\hline
\end{tabular}




\section{Sonuç ve Öneriler}

Sonuç olarak doğum sonu dönemde annelerin fonksiyonel durum ve yorgunluk düzeylerinde meydana gelen değişimler altıncı aydan sonra bile devam edebilmektedir. $\mathrm{Bu}$ durumun hem anne hem de yenidoğan sağlığı üzerinde olumsuz etkileri olmaktadır. Yorgunluk ve fonksiyonel durumun ilişkisini anlamak doğum sonu dönemde annelere kanıta dayalı ve kaliteli bir bakım sunabilmek için önemlidir. İki faktör arasındaki ilişki tanımlandığında yorgunluk ve fonksiyonel durumun birbirini nasıl etkilediği, aralarındaki ilişkinin yönü ve hangi faktörlerden olumsuz etkilendikleri tespit edilebilecektir. Fonksiyonel durum ile yorgunluk genellikle ayrı ayrı çalışmalarda ele alınmış olup iki değişkenin birlikte incelendiği araştırma sayısı sınırlıdır. $\mathrm{Bu}$ çalışmaların sonuçlarına bakılarak iki faktör arasındaki ilişki tam olarak açıklanamamaktır. $\mathrm{Bu}$ nedenle yorgunluk ile fonksiyonel durum arasındaki ilişkinin detaylı açıklanabilmesi için daha çok sayıda çalışmaya ihtiyaç vardır. Yapılan çalışmaların sonuçları, doğum sonu dönemdeki kadınları bütünsel değerlendirme, bakımı planlama ve uygulamada ebelere ve diğer sağlik profesyonellerine yardımcı olabilir.

\section{Kaynaklar}

1. Fathi F, Mohammad-Alizadeh-Charandabi S, Mirghafourvand M. Maternal self-efficacy, postpartum depression, and their relationship with functional status in Iranian mothers. Women Health. 2018;58(2):188-203.

2. Şanlı Y, Öncel S. Kadınların doğum sonrası fonksiyonel durumları ve etkileyen faktörlerin belirlenmesi. Journal of Turkish Society of Obstetric and Gynecology. 2014;11(2):105-14.

3. Fawcett J, Tulman L, Myers ST. Development of the inventory of functional status after childbirth. J Nurse Midwifery. 1988;33(6):252-60.

4. Doering Runquist JJ, Morin K, Stetzer FC. Severe fatigue and depressive symptoms in lower-income urban postpartum women. Western Journal of Nursing Research. 2009;31(5):599-612.

5. Abushaikha L, Safadi R, Ahmad M. Assessing the association between fatigue and functional status during postpartum. Sex Reprod Healthc. 2018;18:19-23.
6. Wang TJ. Concept analysis of functional status. Int J Nurs Stud. 2004;41(4):457-62.

7. Bektaş HA, Akdemir N. Kanserli bireylerde fonksiyonel durumun önemi. Anadolu Hemşirelik ve Sağlık Bilimleri Dergisi. 2009;12(3):54-60.

8. Barkin J, Wisner K, Bromberger J, Beach S, Terry M, Wisniewski S. Development of the Barkin Index of Maternal Functioning. Copyright: Mary Ann Liebert, Inc. 2010.

9. Özkan S, Sevil Ü. Doğum sonrası fonksiyonel durum envanterinin geçerlilik güvenilirlik çalışması. TSK Koruyucu Hekimlik Bülteni. 2007;6(3):199-208.

10. McVeigh CA. Investigating the relationship between satisfaction with social support and functional status after childbirth. MCN: The American Journal of Maternal/Child Nursing. 2000;25(1):25-30.

11. Barbacsy-MacDonald I. Physical activity and postpartum functional status in primiparous women [Doctoral dissertation]. Canada: Queen"s University; 2011.

12. Aktan. Functional status after childbirth and related concepts. Clin Nurs Res. 2010;19(2):16580.

13. McVeigh CA. Anxiety and functional status after childbirth. Australian College of Midwives Incorporated Journal. 2000;13(1):14-8.

14. NANDA. International Nursing Diagnoses: Definitions \& Classification, 2015-2017. 10 ed: Wiley Blackwell; 2014.

15. Yurtsever S. Kronik hastaliklarda yorgunluk ve hemşirelik bakımı. CÜHYO Dergisi. 2000;4(1):16-20.

16. Ergen E. Yorgunluk ve başa çıkma yolları: Nobel Yayınc1lik; 2002.

17. Troy NW, Dalgas-Pelish P. The effectiveness of a self-care intervention for the management of postpartum fatigue. Appl Nurs Res. 2003;16(1):38-45.

18. Troy NW. Is the significance of postpartum fatigue being overlooked in the lives of women? MCN: The American Journal of Maternal/Child Nursing. 2003;28(4):252-7.

19. Tobback E, Behaeghel K, Hanoulle I, Delesie L, Loccufier A, Van Holsbeeck A, et al. Comparison of subjective sleep and fatigue in breast- and bottle-feeding mothers. Midwifery. 2017;47:22-7.

20. Callahan S, Séjourné N, Denis A. Fatigue and breastfeeding: an inevitable partnership? Journal of Human Lactation. 2006;22(2):182-7. 
21. Lai YL, Hung CH, Stocker J, Chan TF, Liu Y. Postpartum fatigue, baby-care activities, and maternal-infant attachment of vaginal and cesarean births following rooming-in. Appl Nurs Res. 2015;28(2):116-20.

22. Giallo R, Seymour M, Dunning M, Cooklin A, Loutzenhiser L, McAuslan P. Factors associated with the course of maternal fatigue across the early postpartum period. Journal of Reproductive and Infant Psychology. 2015;33(5):528-44.

23. Giallo R, Wade C, Cooklin A, Rose N. Assessment of maternal fatigue and depression in the postpartum period: support for two separate constructs. Journal of Reproductive and Infant Psychology. 2011;29(1):69-80.

24. Gozum S, Kilic D. Health problems related to early discharge of Turkish women. Midwifery. 2005;21(4):371-8.
25. Aksu S, Varol FG, Hotun Sahin N. Long-term postpartum health problems in Turkish women: prevalence and associations with self-rated health. Contemp Nurse. 2017;53(2):167-81.

26. Badr HA, Zauszniewski JA. Meta-analysis of the predictive factors of postpartum fatigue. Appl Nurs Res. 2017;36:122-7.

27. Taylor J, Johnson M. The role of anxiety and other factors in predicting postnatal fatigue: from birth to 6 months. Midwifery. 2013;29(5):52634.

28. Çolak MB, Akın B, Turfan EÇ. İlk kez doğum yapan kadınlarda doğum şeklinin postpartum yorgunluk ve yaşam kalitesi üzerindeki etkisinin değerlendirilmesi. Life Sciences. 2019;14(2):3040 . 